\title{
知床国立公園を事例とした自然公園における利用者 意識の把握手法に関する一考察
}

\author{
A Study on the Investigation Method of Visitors' Perception in Protected Area -Shiretoko National Park- \\ 小林 昭裕* \\ Akihiro KOBAYASHI
}

\begin{abstract}
Each case study for examining visitors' perception is often based on the fragmented information obtained from a sampling investigation that has been conducted at a certain place and time. Moreover, this method cannot monitor the secular variation and trend in population; and, as a result, we cannot help limiting the interpretation of the results obtained from the investigation. However, until recently, the secular variation and trend within the population has not been examined using the method involving the collection of data from a certain place at a certain time. Furthermore, the subjects in the investigation technique that is applied to capture the secular or seasonal variation in the population have hardly been discussed. This study was conducted in order to examine the problem involved in the method for investigating visitors' perception in a protected area and to obtain the pointers for further improvement. In this research, the reproducibility and stability of the results of sampling were verified on the basis of the questionnaire from a mail-back survey. The survey was part of an annual investigation conducted in Shiretoko National Park, where the recreational conditions have been changed.
\end{abstract}

Keywords: sampling, method, visitor, perception, protected area, Shiretoko national park キーワード：サンプリング, 方法, 利用者, 意識, 自然公園, 知床国立公園

\section{1. 緒言}

自然公園利用の調查手法は大きく分けて，利用者数や利用動態 を可視的に把握する手法と, 可視できない利用者意識の把握手法 とがある ${ }^{1)}$ 。可視的把握手法については, カウンターなど自動計 測装置やビデオ撮影, GPS を用いた手法など2)，新技術の導入が 目覚ましい。また, 利用動態把握手法に関する研究についても, 海外の知見を含めて体系化が試みられ ${ }^{3)}{ }^{4)}$, 進展しつつある。

一方, 自然公園の利用者意識(ここでは利用者の認知, 心理, 評価を対象とする)の把握については, 事例調查毎に, ある場所, ある時期でのサンプリング調查による断片的情報をもとにする場 合がほとんどである。調查手法は都市公園での利用者意識調查の 手法を援用することが多い。都市公園と自然公園, いずれも利用 者意識調査はサンプリング調査であり, 母集団の特性を社会統計 学的に推計する手法をとる。都市公園, 特に住区基幹公園や都市 基幹公園を対象とする場合は，母集団は誘致圈の推定に見られる ように，公園周辺に居住する人々を主対象とすることから，母集 団となる地域住民の多くが数年のうちに移住することは稀であり, 母集団は安定している。一方, 自然公園の場合, 母集団である利 用者の多くは毎年同じではない。

また, 自然公園での調査は, 年間の最も利用者数の多い時期を 選んで実施されることが多く ${ }^{5)}$, 季節が異なると, 利用特性だけ でなく環境への選好が異なる点が指摘されている ${ }^{6)}$ 。また, 公園 内の施設や管理など, 状況が変化した場合, 利用者集団が置き換 わることも海外の文献で指摘されている ${ }^{7)}$ 。具体的には, 利用者 が増加すると, 混雑を不快に感ずる利用者は他の場所へ移り, 相 対的に混雑を気にしない利用者に置き換わることによって, 利用 者数の増加にもかかわらず, 満足度が低下しないといったことが おきる。知床国立公園の事例調査から, 調查年による違いが確認 されたことは, これまで単年度調査の利用者意識の解釈に, 調查 年前後に公園利用を取り巻く環境変化が利用者の意識に及ぼす変 化を考慮する必要があることが示唆されている ${ }^{8)}$ 。
一年の特定の時期に特定の場所に限定した利用者意識調査では, 母集団の経時的変化を捕捉できないため, 結果の解釈も限定的と ならざるを得ない。しかしながら，これまで自然公園利用を対象 に，同一地点で同一な方法で得たデー夕をもとに，母集団の特性 の経年的変化が論じられたことはない。

そこで, 本研究では, ここ数年, 利用を取り巻く環境が変化し つつある知床国立公園を対象に，経年調査で得た結果をもとに， 従前の単年度調査結果の再現性や, 利用を取り巻く環境が変化し た場合のサンプリング結果の安定性などについて, 検証すること とした。そして, 結果から得た知見をもとに, 単年度・1箇所で 行ったサンプリング調査で得た結果の解釈, 母集団の特性に変化 が起きている可能性に対応した調査手法上の課題などについて検 討し, 自然公園における利用者意識の把握手法の改善の手がかり を得ることを目的に本研究を行った。

\section{2. 調查方法}

\section{（1）事例対象とした知床国立公園の概況}

1964 年に指定された知床国立公園は, 険しい火山連峰と原生 林に覆われた山岳景観や豪壮な海岸景観および多様で豊富な野生 動物の生息と相俟って, わが国有数の極めて原始性の高い国立公 園である。公園区域に隣接する斜里町ウトロ地区の観光温泉街や 羅臼市街は, 宿泊施設やビジターセンターなどが整備された利用 拠点である。半島の先端部分は無車道区域であり, 公園内の車で の移動は, ウトロから知床五湖を経てカムイワッカ, 知床横断道 路を経て羅且から海岸線を相泊までと経路が限定されている（図一 1 )。また, 歩道は知床五湖と知床連山, 羅臼湖, 知床岳へのア クセスがあるのみで, 多くの利用者は知床五湖, カムイワッカ, 知床連山, 知床遊覧船を利用する。指定当時 40 万人だった年間 利用者は，現在約 240 万人を数える。

また, 1999 年から 2007 年にかけて, 利用を取り巻く環境の変 化としては 1999 年から知床五湖とカムイワッカの間に車両規制

*専修大学北海道短期大学 みどりの総合科学科 


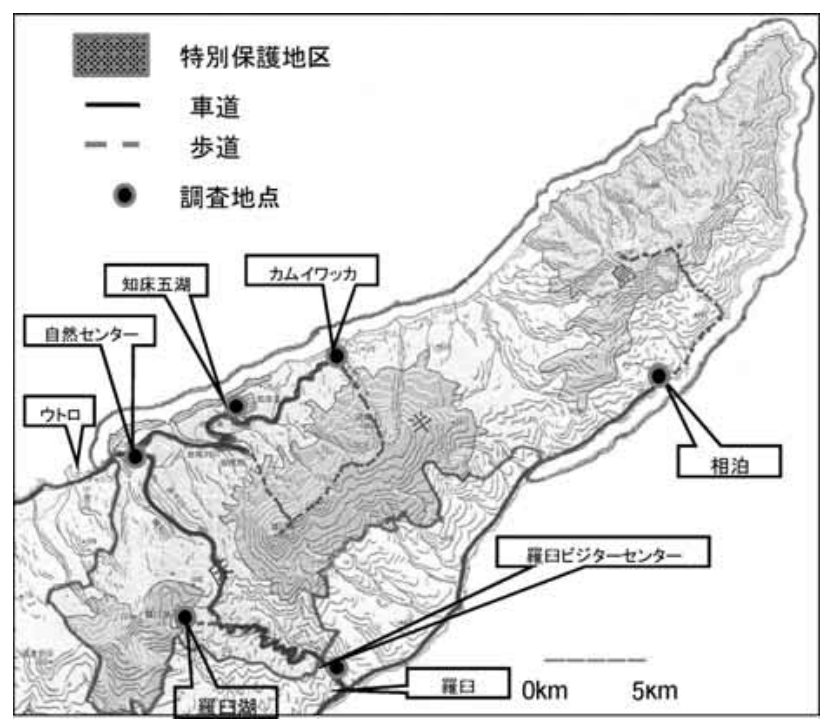

図-1＼cjkstart調査対象地と調査地点およびアクセス

が導入され，1999 年は 7 月下旬からお盆までの 16 日間， 2000 年 から 2004 年までは 23 日間で, その前後は一般車両の利用が可能 であった。2005 年には世界自然遺産に登録され，2005 年以降は 7 月 13 日〜 9 月 20 日まで, シャトルバスでのカムイワッカへの アクセスが可能で，それ以外の期間は立ち入りが禁止された。 2006 年以降, 先端部地区への立ち入り自肃要請が出され, また, それまでカムイワッカ湯の滝への利用は四の滝までのアクセスが できたが，落石の危険性から一の滝までのアクセスに制限された。

\section{（2）利用者への意識調査方法}

知床国立公園の利用者に対するアンケート調查(目的は車両規 制に関する意識調査)を，1999 年から毎年夏期に 2008 年まで継 続して筆者が主体となり実施した。本研究では 1999 年から 2007 年に実施したアンケート結果を対象とした。本研究の目的と異な る目的で実施されたアンケートであるものの, モニタリングの観 点から同一の設問を行っていることから，それらを対象とした。 「調査では, 無作為性を確保するため, 調査地点を通過する利用 者に対し, 調查員が随時調査を依頼し, 調査に協力いただける方 にアンケートを同封した封筒を配布し，郵送による回答を求めた。 9 年間は同じ方法で行った。配布は, 知床五湖, カムイワッカ, 羅臼湖, 羅臼ビジターセンターなど (図一 1 ), 主要な立ち寄り 箇所で実施した。

$7 \sim 9$ 月の知床五湖周辺への来訪者が, 最も利用者数の多かっ た 2005 年で 33 万人であり ${ }^{9)}$, 信頼度 $95 \%$ で母比率を $10 \%$ とし, サンプリング䛊差を $1 \%$ 以内に収めたい場合，少なくとも 350 件のサンプリングを行う必要がある ${ }^{10)}$ 。調査地 2 箇所の母集団は, 調査期間（ 7 月～9月）の来訪者数は, 調査期間年のうち, カム イワッカで 2005 年に最大で 47,446 人, 知床五湖で 2,006 年に最 大で 268,627 人であり, 必要なサンプル数は, カムイワッカで 50 人, 知床五湖で 285 人であり, 2001 年度の知床五湖を除き, 各 年度のサンプル数はそれを上回ることから, 夏季利用者の母集団 の特性を一定程度反映していると考えられる。

\section{(3) 利用者数の経年変化}

2002 年から 2007 年におけるカムイワッカ行のバス利用者数に ついて ${ }^{9)}$, 車両規制期間は毎年日付が若干異なることから, 同じ 日付として, 8 月 1 日から 8 月 18 日までの利用者数の増減を比 較した。いずれも，8月 10 日以降扔盆過ぎまでが最も過密な傾 向を示した。なかでも世界遺産登録前年の 2004 年, 登録年の 2005 年での利用者数が他の年度と比べて 20 ～ $0 \%$ 近く増加した。
表－1アンケートの配付および回収状況（1999-2007）

\begin{tabular}{|c|c|c|c|c|c|c|c|c|}
\hline & \multicolumn{3}{|c|}{ 配布数 } & \multicolumn{2}{|c|}{ 回収数 } & \multicolumn{3}{|c|}{$\begin{array}{l}\text { 回収率 (\%) } \\
\end{array}$} \\
\hline 調査年 & $\begin{array}{l}\text { カムイ } \\
\text { ワッカ }\end{array}$ & $\begin{array}{l}\text { 知床 } \\
\text { 五湖 } \\
\end{array}$ & 全体 & $\begin{array}{l}\text { カムイ } \\
\text { ワッカ }\end{array}$ & $\begin{array}{l}\text { 知床 } \\
\text { 五湖 } \\
\end{array}$ & $\begin{array}{l}\text { カムイ } \\
\text { ワッカ }\end{array}$ & $\begin{array}{l}\text { 知床 } \\
\text { 五湖 } \\
\end{array}$ & 全体 \\
\hline 1999 & 658 & 1030 & 2883 & 205 & 247 & 31.3 & 24 & 27.6 \\
\hline 2000 & 1191 & 1286 & 2447 & 326 & 309 & 28.3 & 27.3 & 27.6 \\
\hline 2001 & 829 & 1961 & 2883 & 220 & 501 & 26.7 & 27.2 & 27.3 \\
\hline 2002 & 1268 & 1438 & 2706 & 307 & 347 & 24.2 & 24.1 & 26 \\
\hline 2003 & 1122 & 1310 & 2995 & 294 & 416 & 26.2 & 31.8 & 27.2 \\
\hline 2004 & 796 & 1080 & 2998 & 215 & 301 & 37.8 & 19.9 & 24.7 \\
\hline 2005 & 1527 & 2167 & 3894 & 314 & 553 & 20.6 & 25.5 & 24 \\
\hline 2006 & 379 & 2663 & 3202 & 102 & 531 & 26.9 & 19.9 & 21.3 \\
\hline 2007 & & 1626 & 1626 & 0 & 335 & & 21.5 & 21.6 \\
\hline
\end{tabular}

\section{表 -2 調査年における属性の違い(分散分析)}

\begin{tabular}{lllll}
\hline \hline \multicolumn{5}{c}{ 調查地ワッカ } \\
\hline \hline
\end{tabular}

知床五湖駐車場での乗用車, 大型バスの年間駐車台数（4 月末 $\sim 11$ 月初旬） ${ }^{99}$, 世界遺産登録年の 2005 年以降, 以前と比べ, 20 40\%近く増加した。調査期間にあたる繁忙期の乗用車の利用 台数は世界遺産登録年と翌年は $20 \%$ 近く増加した。

\section{（4）経年による比較対象とした設問項目}

比較対象については, 設問および回答方式が同一の設問を対象 とした。調查対象としたのは, 調査方法にかかわる調査地点, 今 回の事例対象では利用形態の違いとなるカムイワッカへの来訪, また，「個人属性」では性別，年齢，住所，集団人数，職業，交 通手段, 知床の来訪歴, 滞在日数とした。設問のうちから,「車 両規制に関する最初の情報源」として 15 項目（該当する，しな い),「車両規制」に関する設問として 4 項目,「利用行動」につ いて 17 項目（訪れる, 訪れない）を対象とした。また, 分析対 象は, 1999 年から 2007 年までの調査結果のうち, 調査地点とし て継続的に用いた知床五湖 (以下，五湖), カムイワッカ(以下, ワッカ)で配布されたアンケート結果に限定した。

\section{3 . 結果}

\section{（1）アンケートの回収率の経年変化}

調査地ワッカの回収率は 1999 年から 2003 年まで派減傾向, 2004 年以降, 増減の変化が大きくなった。調査地五湖の回収率 は, 1999 年から 2002 年まで横ばい傾向, 2003 年以降, 増減の変 化が大きくなり，逓減傾向を示した（表一 1 )。

\section{（2）個人属性における調査年による差異}

五湖，ワッカそれぞれの調査地で利用者に意識調査を依頼した ことから, 個人属性の違いについて, 調査地ごとに調査年を要因 として分散分析を行い, Scheffe の多重比較検定により調查年の 対比較を行った。分散分析の結果, 個人属性の 8 項目のうち, 調 查地ワッカでは次の 6 項目, 性別, 年齢, 集団人数, 職業, 滞在 日数に有意差がみられた（表 -2$)$ 。調查地五湖では次の 7 項目, 性別, 年齢, 居住地域, 集団人数, 職業, 交通手段, 滞在日数に 有意差がみられた。雨調查地に共通して有意差がみられたのは 5 項目であった。

多重比較検定の結果を整理した（表－3）。有意差を示した対 象を示すと, 性別について, 調査地五湖では 1999 年, 2003 年, それら以外に区分された。99 年は男性の割合が多く, 2003 年は 女性の割合が多かった。年齢について, 調査地ワッカ之調査地五 湖では 2005 年と 2006 年を除き, 各年度間で有意差が見られた。 
表一 3 調查地およびカムイワッカ来訪別にみた、個人属性 における調査年による差異(多重比較検定)

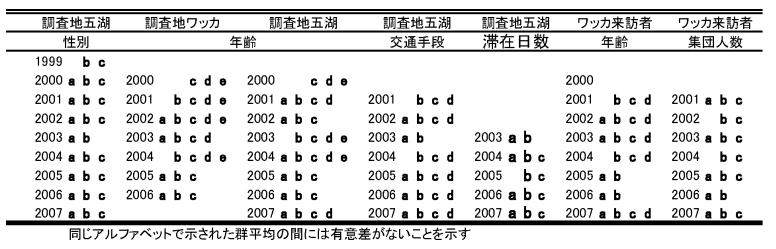

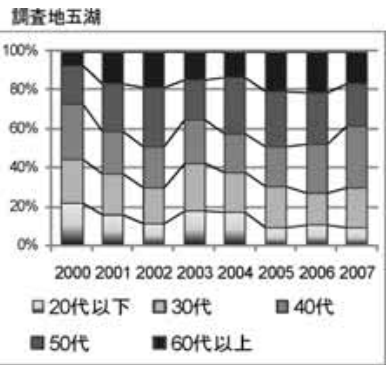

図ー 2 調査地ワッカおよび五湖における回答者の年齢構成の経年变化
表一 5 調查地別にみた、車両規制に関する最初の情報源における調査 年による差異(多重比較検定)

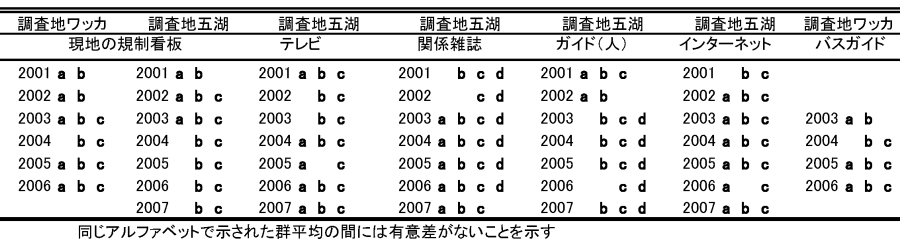

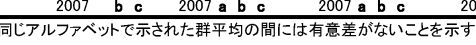

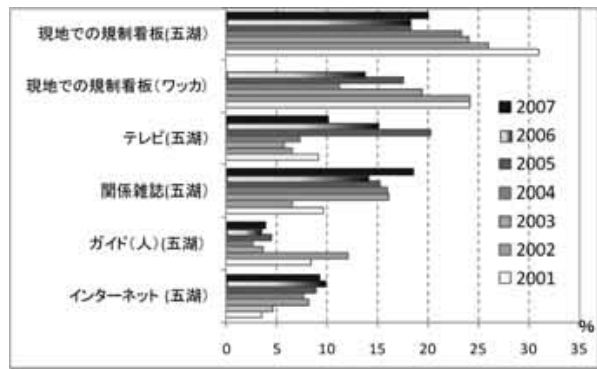

図－３車両規制に関する最初の情報源にみる経年変化
調査地ワッカでは, 20 代以下, 30 代の割合に多少の増減がある ものの減少傾向を示した (図一2)。交通手段について, 調査地 五湖では, 2003 年, 2001 年と 2004 年, それ以外に区分された。 滞在日数について, 調査地五湖では, 2003 年, 2005 年, それ以 外に区分された。

散策利用が主体の五湖よりも奥地に位置し, 湯の滝を目当てに するカムイワッカの利用形態抢よびアクセスの違い考慮し, カム イワッカの来訪(以下, ワッカ来訪) の有無で区別し, 調查年を 要因として分散分析を行い, Scheffe の多重比較検定により調査 年の対比較を行った（表一 2 )。ワッカ来訪者では次の 4 項目年 齢, 居住地域, 集団人数, 職業に有意差がみられた。ワッカ非来 訪者では次の 4 項目, 年齢, 居住地域, 職業, 交通手段に有意差 がみられた。両調査地に共通して有意差がみられたのは 3 項目で あった。

多重比較検定の結果を整理した(表一 3 )。有意差を示した対象 を示すと，年齢について， ワッカ来訪者では， 2005 年と 2006 年, 2002 年と 2003 年と 2007 年, 2001 年と 2004 年に区分された。集 団人数について, ワッカ来訪者では, 2002 年と 2004 年, 2006 年, それ以外に区分された。

\section{（３）車両規制に関する情報源の調査年による差異}

車両規制に関する最初の情報源としての 15 項目（現地の規制 看板, テレビ, 関係雑誌, ガイド (人), インターネット, 道の 駅, レンタカー会社, バスガイド, ラジオ, ビジターセンター, 新聞, 旅行会社の案内, 友人・知人, キャンプ場, 現地の宿泊施 設）について, 調査地ごとに調査年を要因として分散分析を行い, Scheffe の多重比較検定により調査年の対比較を行った。分散分

\section{表 -4 調査年における車両規制に関する最初の情報源の違い} (分散分析)

\begin{tabular}{|c|c|c|c|c|}
\hline & 調査地ワッカ & 調査地五湖 & ワッカ来訪者 & 韭来訪者 \\
\hline 現地の規制看板 & $* *$ & $* * *$ & $*$ & $* * *$ \\
\hline テレビ & ** & $* * *$ & ** & - \\
\hline 関係雑誌 & - & $* * *$ & - & $* * *$ \\
\hline ガ价 (人) & - & $* * *$ & - & - \\
\hline インターネット & - & $* * *$ & - & $* * *$ \\
\hline 道の駅 & * & $*$ & * & - \\
\hline レンタカー会社 & - & - & * & - \\
\hline バスガイド & * & - & * & - \\
\hline ラジオ & - & - & - & - \\
\hline ビジターセンター & - & - & - & - \\
\hline 新聞 & - & - & - & - \\
\hline 旅行会社の案内 & - & - & - & - \\
\hline 友人.知人 & - & - & - & - \\
\hline キャンプ場 & - & - & - & - \\
\hline 現地の宿泊施設 & - & - & - & - \\
\hline
\end{tabular}

析の結果（表－4）, 調査地ワッカでは次の 4 項目, 現地の規制 看板，テレビ，道の駅，バスガイドについて有意差がみられた。 調査地五湖では次の 6 項目, 現地の規制看板, テレビ, 関係雑誌, ガイド (人), インターネット, 道の駅について有意差がみられ た。両調査地に共通して有意差がみられたのは 3 項目であった。

多重比較検定の結果を整理した（表－5 )。有意差を示した対 象を示すと，現地の規制看板について，調查地ワッカでは，2004 年, 2001 年 2002 年, それ以外に区分された。調査地五湖では, 2001 年， 2002 年と 2003 年，2004 年〜2007 年に区分された。テ レビについて, 調査地五湖では 2005 年, 2002 年と 2003 年, そ れ以外に区分された。関係雑誌について, 調查地五湖では 2001 年, 2002 年, 2007 年, それ以外に区分された。ガイド (人) に ついて, 調查地五湖では 2001 年, 2002 年, 2006 年, それ以外に 区分された。インターネットについて, 調查地五湖では, 2001 年, 2006 年，それ以外に区分された。

図－3 から調查地五湖では，現地の規制看板について，2001 年が最も多く, 2002 年と 2003 年と低減し， 2004 年 2007 年が 少なかった。調査地ワッカでは，現地の規制看板について，2004 年が最も少なく, 2001 年と 2002 年が多かった。両調査地ともに, その割合は低下傾向を示した。調査地五湖では, テレビについて, 2005 年が多く, 2002 年と 2003 年が少なかった。調查地五湖では, 関係雑誌について 2007 年が多く, 2001 年， 2002 年が少なかった。 調查地五湖では, ガイド（人）について，2001 年，2002 年が多 く, 他は少なかった。調査地五湖では, インターネットについて, 2006 年が多く, 2001 年と 2002 年が少なかった。インターネット と関係雑誌の割合は, 2003 年を境に増加した。

ワッカ来訪の有無で区別し，調查年を要因として分散分析を行 い, Scheffe の多重比較検定により調査年の対比較を行った。分

表一6カムイワッカ来訪別にみた、車両規制 に関する最初の情報源における調査年による 差異(多重比較検定)

\begin{tabular}{|c|c|c|c|}
\hline ワッカ来訪者 & 非来訪者 & 非来訪者 & ワッカ来訪者 \\
\hline テレビ & 関係雑誌 & インターネット & レンタカー会社 \\
\hline $\begin{array}{l}2001 \mathbf{a} \mathbf{b} \mathbf{c} \\
2002 \mathbf{a} \mathbf{b} \mathbf{c} \\
2003 \quad \mathbf{b} \mathbf{c} \\
2004 \mathbf{a} \mathbf{b} \mathbf{c} \\
2005 \mathbf{a} \mathbf{b} \\
2006 \mathbf{a} \mathbf{b} \mathbf{c} \\
2007 \mathbf{a} \mathbf{b} \mathbf{c}\end{array}$ & $\begin{array}{l}2001 \text { b c } \\
2002 \text { a b c } \\
2003 \text { a b c } \\
2004 \text { a b c } \\
2005 \text { a b c } \\
2006 \text { a b c } \\
2007 \text { a b }\end{array}$ & $\begin{array}{l}2001 \text { b c } \\
2002 \text { a b c } \\
2003 \text { a b c } \\
2004 \text { a b c } \\
2005 \text { a b c } \\
2006 \text { a b b } \\
2007 \text { a b c }\end{array}$ & $\begin{array}{l}2001 \text { a b c } \\
2002 \text { a b c } \\
2003 \text { a b c } \\
2004 \text { a b c } \\
2005 \text { b c c } \\
2006 \text { a b } \\
2007 \text { a b c }\end{array}$ \\
\hline
\end{tabular}
散分析の結果 (表一 4)，ワッ カ来訪者では次 の 5 項目, 現地 の規制看板，テ レビ, 道の駅, レンタカー, バ スガイドについ て有意差がみら れた。非来訪者 


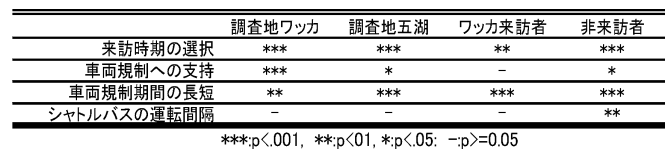

では次の 3 項目，現地の規制看板，関係雑誌，インター ネットについて有意差がみられた。

多重比較検定の結果を整理した（表－6）。有意差を 示した対象を示すと，テレビについて，ワッカ来訪者では 2003 年， 2005 年，それ以外に区分された。関係雑誌について，非来 訪者では, 2001 年, 2002 年 2006 年, 2007 年に区分され, 増加 傾向を示した。インターネットについて，非来訪者では，2001 年, 2006 年, それ以外に区分され, 増加傾向を示した。レンタ カーについて, ワッカ来訪者では 2005 年, 2006 年, それ以外に 区分された。

\section{（4）車両規制に対する評価の調査年による差異}

「来訪時期の選択」，「車両規制への支持」，「車両規制期間の長 短」,「シャトルバスの運転間隔」について, 調査地毎に調査年を 要因として分散分析を行い, Scheffe の多重比較検定により調査 年の対比較を行った。分散分析の結果 (表一 7 ), 調査地ワッカ, 調查地五湖，いずれも，「来訪時期の選択」，「車両規制への支持」, 「車両規制期間の長短」について有意差がみられた。両調査地に 共通して有意差がみられたのは 2 項目であった。

多重比較検定の結果を整理した(表一8)。有意差を示した対象 を示すと,「来訪時期の選択」, について, 調查地ワッカでは, 2003 年, 2004 年〜2005 年, 2006 年に区分された。“現地に来る まで規制を知らなかったので考慮できなかった”割合は, 2004 年〜2005 年が他の年度に比べ少なかった（図－4）。調查地五湖 では, 2003 年〜2004 年, 2005 年, 2006 年 2007 年に区分され た。“現地に来るまで規制を知らなかったので考慮できなかった” 割合は, 2005 が他の年度に比べ少なかった（図－5）。「車両規 制への支持」について, 調査地ワッカでは, 2003 年と 2004 年, 2005 年, 2006 年に区分された。「必要であり, 理解する」の割合 は，2004 年以前に比べ，2005 年以降が多かった（図-6)。「車 両規制期間の長短」調查地ワッカでは, 2002 年, 2005 年, それ 以外に区分された。調查地五湖では, 2000 年と 2002 年, 2001 年 と 2004 年， 2003 年， 2005 年， 2006 年， 2007 年に区分された。 調查地ワッカでは 2005 年以降, 調查地五湖では 2004 年以降, “むう少し長くてもよい”割合は, それ以前と比べ少なかった (図-7)。

ワッカ来訪の有無で区別し, 調查年を要因として分散分析を行 い, Scheffe の多重比較検定により調査年の対比較を行った。分 散分析の結果 (表一 7), ワッカ来訪者では, 「来訪時期の選択」, 「車両規制期間の長短」ついて有意差がみられた。非来訪者では, 「来訪時期の選択」, 「車両規制への支持」, 「車両規制期間の長短」, 「シャトル運行バスの運転間隔」いずれも有意差がみられた。両 調查地に共通して有意差がみられたのは 2 項目であった。

多重比較検定の結果を整理した（表－9）。「来訪時期の選択」, について，ワッカ来訪者，非来訪者いずれむ， 2003 年, 2004 年と 2005 年, 2006 年と 2007 年に区分された。「車両規制期間の長短」に ついて，ワッカ来訪者では 2002 年，2005 年 と 2006 年, それ以外に区分された。「車両規 制期間の長短」について, 非来訪者では 2001 年と 2004 年, 2002 年, 2003 年, 2005 年， 2006 年亡 2007 年に区分された。

（５）利用行動の調査年による差異

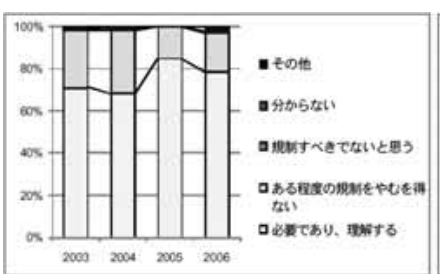

図ー6 調査地ワッカでの「車両規 制への評価」の経年変化

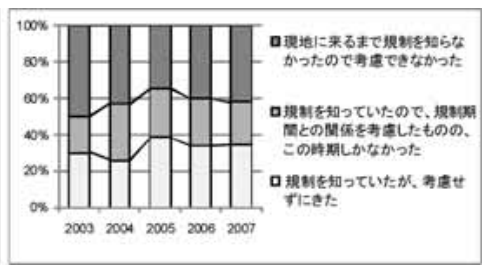

図ー 5 調査地五湖における「来訪 時期の選択」の経年変化
知床での利用行動を問うた 17 の設問項目（遊覧船からの断崖 や山々の眺め, 知床連山への登山, 羅臼湖へのハイキング, 遊漁 船での魚鈞り・川釣り, 知床五湖の遊歩道の散策, カムイワッカ での入浴，フレペの滝や遊歩道の散策，風景や植物の写真撮影， 知床横断道路沿線之峠からの眺め, ウトロからの夕焼けの眺め, ウトロや羅臼の野営場でのキャンプ, 岩尾別・セセキ・熊の湯で の入浴, 野生動物の写真撮影・観察, 自然センターの見学, エコ ッアーに参加，シーカヤックに乗る，バードウオッチング）につ いて, 調査地ごとに調查年を要因として分散分析を行い, Scheffe の多重比較検定により調査年の対比較を行った。分散分 析の結果（表-10，調查地ワッカでは 10 項目, 調查地五湖では 10 項目に有意差がみられ，両調查地に共通して有意差がみられ たのは次の 6 項目, “知床五湖の遊歩道の散策”, “カムイワッカ での入浴”，“知床横断道路沿線と峠からの眺め”，“エコッアーに 参加”, “野生動物の写真撮影・観察”，“シーカヤックに乗る”で あった。

多重比較検定の結果を整理した（表－11）。有意差を示した対 象を示すと, 知床五湖の遊歩道の散策について, 調查地ワッカで は 2003 年, 2004 2006 年に, 調査地五湖では 2003 年〜2004 年, 2005 年 2007 年に区分された。カムイワッカでの入浴について,

\section{表ー8 調査地別にみた、車両規制に対する評価の調査年による} 差異(多重比較検定)

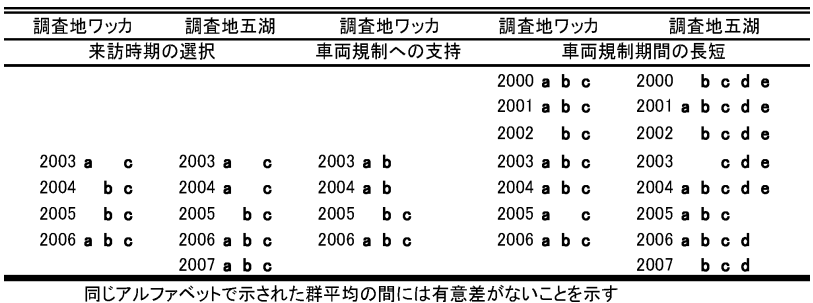

表－9 カムイワッカ来訪別にみた、車両規制に対する評価の調 查年による差異(多重比較検定)

\begin{tabular}{|c|c|c|c|c|}
\hline ワッカ来訪者 & 非来訪者 & ワッカ来訪者 & 非来訪者 & 非来訪者 \\
\hline \multicolumn{2}{|c|}{ 来訪時期の選択 } & \multicolumn{2}{|c|}{ 車両規制期間の長短 } & シャトルパスの運転間隔 \\
\hline & & 2001 a b c & 2001 a b c d e & $2001 \mathrm{ab}$ \\
\hline & & 2002 a c & 2002 b c d e & 2002 a b c \\
\hline $2003 \mathbf{a} \mathbf{b}$ & $2003 \mathbf{a} \mathbf{b}$ & 2003 a b c & ode & \\
\hline 2004 b c & 2004 b c & 2004 a b c & 2004 a b c d e & 2004 a b c \\
\hline & 2005 & 2005 a b & 2005 a b c & 2005 a b c \\
\hline 2006 a b c & 2006 a b o & $2006 \mathbf{a b}$ & 2006 a b o d & 2006 b c \\
\hline 2007 a b & $2007 \mathrm{a} \mathrm{b} \mathrm{c}$ & 2007 a b c & 2007 a b c d & 2007 a b c \\
\hline
\end{tabular}

同じアルフアベットで示された群平均の間には有意差がないことを示す

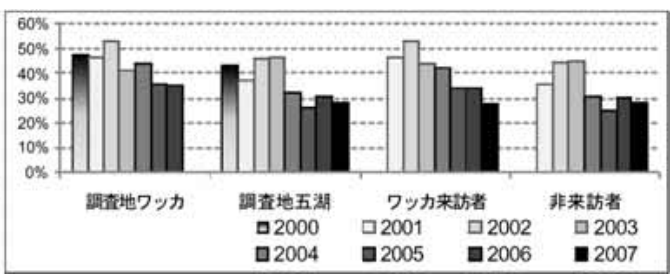

図- 7 車両規制期間を “もう少し長くてもよい” とする割合の経年変化 
表 -10 利用行動の調査年による差異（分散分析）

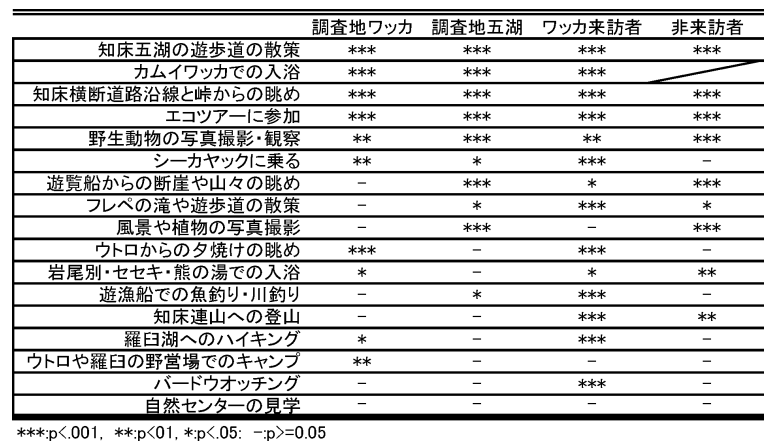

調查地ワッカでは, 2004 年とそれ以外, 調查地五湖では, 2003 年, 2004 年 2007 年に区分された。知床横断道路沿線と峠から の眺めについて, 調査地ワッカでは, 2003 年, 2004 年, 2005 年 〜2006 年に区分され, 調查地五湖では, 2004 年とそれ以外に区 分された。エコッアーに参加では, 調査地ワッカでは 2003 年〜2 005 年, 2006 年に区分され, 調查地五湖では 2003 年, 2004 年〜 2005 年, 2006 年, 2007 年に区分された。野生動物の写真撮影・ 観察について, 調査地ワッカでは 2003 年, 2004 年, 2005 年〜20 06 年に区分され, 調查地五湖では 2003 年〜2004 年, 2005 年〜 2007 年に区分された。遊覧船からの断崖や山々の眺めについて, 調查地五湖では, 2004 年とそれ以外に区分された。風景や植物 の写真撮影について, 調查地五湖では 2003 2005 年, 2006 年〜 2007 年に区分された。ウトロからの夕焼けの眺めでは, 調査地 ワッカで 2003 年 2004 年, 2005 年, 2006 年に区分された。岩 尾別・セセキ・熊の湯での入浴について, 調査地ワッカでは, 2003 年, 2004 年, 2005 年 2006 年に区分された。ウトロや羅臼 の野営場でのキャンプについて, 調査地ワッカで, 2003 年, 2004 年, 2005 年〜2006 年に区分された。

ワッカ来訪の有無で区別し, 調查地ごとに調査年を要因として 分散分析を行い, Scheffe の多重比較検定により調査年の対比較 を行った。分散分析の結果 (表-10), ワッカ来訪者では, 17 項 目のうち 14 項目で, 非来訪者では 9 項目に有意差がみられ, 両 調查地に共通して有意差がみられたのは次の 8 項目, “知床五湖 の遊歩道の散策”, “知床横断道路沿線之峠からの眺め”, エコッ アーに参加”, “野生動物の写真撮影・観察”, “遊覧船からの断崖

表ー13調査地点別にみた、利用行動の選択にみる経年変化 (2003 2007)

\begin{tabular}{|c|c|c|c|c|c|}
\hline & 2003 & 2004 & 2005 & $2006 \quad 2007$ & \\
\hline 知床五湖の遊步道の散策(ワッカ) & 73.5 & 56.3 & 51.9 & $44.1 /$ & *** \\
\hline $\begin{array}{l}\text { 知床五湖の遊歩道の散策 (五湖) } \\
\end{array}$ & 77.9 & 87.4 & 52.3 & $\begin{array}{ll}54.4 & 51.9 \\
\end{array}$ & $* * *$ \\
\hline カムイワッカでの入浴(ワッカ) & 45.2 & 81.4 & 45.9 & $40.2<$ & $* * *$ \\
\hline $\begin{array}{r}\text { カムイワッカでの入浴(五湖) } \\
\end{array}$ & 36.5 & 23.6 & 18.1 & $\begin{array}{ll}18.3 & 16.7 \\
\end{array}$ & $* * *$ \\
\hline 知床横断道路沿線と趾からの眺め (ワッカ) & 43.5 & 55.4 & 38.9 & 35.3 & $* * *$ \\
\hline 知床棤断道路沿線と峠からの眺め(五湖) & 43.5 & 55.5 & 36.9 & 36.9 & $* * *$ \\
\hline エココツアーに参加(ワッカ) & 1.7 & 0.5 & 4.5 & 16.7 & *** \\
\hline $\begin{array}{l}\text { エコッアーに参加 (五湖) } \\
\text { エ }\end{array}$ & 1.2 & 2.0 & 5.4 & 10.0 & $* * *$ \\
\hline 野生動物の写真撮影·観察 (ワッカ) & 44.9 & 44.2 & 33.4 & 28.4 & ** \\
\hline 野生動物の写真撮影·観察 (五湖) & 46.6 & 45.2 & 30.0 & 26.4 & **** \\
\hline 遊覽船からの断崖や山々の眺め (五湖) & 32.0 & 54.2 & 34.9 & 30.7 & $* * *$ \\
\hline 風景や植物の写真撮影(五湖) & 34.9 & 34.6 & 35.1 & 14.1 & $* * *$ \\
\hline ウトロからの夕焼けの眺め(ワッカ) & 16.0 & 15.4 & 28.0 & 20.8 & **** \\
\hline 岩尾別·セセキ·熊の湯での入浴(ワッカ) & 15.0 & 25.6 & 21.7 & 19.6 & $*$ \\
\hline ウトロや羅臼の野営場でのキャンプ(ワッカ) & 5.8 & 14.9 & 10.5 & 8.8 & ** \\
\hline
\end{tabular}

表ー14 ワッカ来訪別にみた、利用行動の選択にみる経年変化 (2003 2007)

\begin{tabular}{|c|c|c|c|c|c|c|}
\hline & 2003 & 2004 & 2005 & 2006 & 2007 & \\
\hline 知床五湖の遊歩道の散策(ワッカ来訪) & 71.3 & 62.6 & 54.8 & 52.8 & 60.7 & $* * *$ \\
\hline 知床五湖の遊歩道の散策(非来訪) & 84.1 & 89.1 & 49.7 & 52.8 & 50.2 & $* * *$ \\
\hline $\begin{array}{l}\text { カムイワッカでの入浴(ワッカ来訪) } \\
\end{array}$ & 63.9 & 86.0 & 58.9 & 69.4 & 7 & **** \\
\hline 知床横断道路沿線と峠からの眺め(ワッカ来訪) & 43.1 & 55.9 & 40.6 & 41.7 & 42.9 & ***** \\
\hline 知床横断道路沿線と峠からの眺め(非来訪) & 44.3 & 54.8 & 34.9 & 34.3 & 34.4 & ***** \\
\hline $\begin{array}{l}\text { エコツアーに参加(ワッカ来訪) } \\
\end{array}$ & 2.0 & 1.1 & 7.5 & 19.6 & 8.9 & $* * *$ \\
\hline エコツアーに参加(非来訪) & 0.4 & 1.7 & 2.9 & 7.1 & 6.5 & $* * *$ \\
\hline 野生動物の写真撮影·観察(ワッカ来訪) & 48.0 & 44.8 & 37.2 & 35.7 & 41.1 & *** \\
\hline 野生動物の写真摄影·観察 (非来訪) & 42.4 & 44.8 & 25.8 & 22.6 & 26.5 & $* * *$ \\
\hline $\begin{array}{c}\text { シーカヤックに乗る(ワッカ来訪) } \\
\end{array}$ & 1.6 & 0.7 & 4.8 & 8.5 & 12.5 & $* * *$ \\
\hline 遊覧船からの断崖や山々の眺め(非来訪) & 35.6 & 56.5 & 32.7 & 27.9 & 32.3 & $* * *$ \\
\hline フレペの滝や遊歩道の散策(ワッカ来訪) & 18.6 & 18.5 & 27.1 & 32.2 & 41.1 & **** \\
\hline $\begin{array}{c}\text { 風景や植物の写真撮影(非来訪) } \\
\end{array}$ & 37.5 & 35.7 & 32.5 & 9.7 & 9.7 & $* * *$ \\
\hline ウトロからの夕焼はの眺め(ワッカ来訪) & 19.3 & 17.1 & 30.0 & 32.8 & 50.0 & $* * *$ \\
\hline 岩尾別·セセキ·熊の湯での入浴(非来訪) & 6.8 & 6.1 & 8.4 & 3.0 & 9.0 & ** \\
\hline 遊漁船での魚釣り・川釣り(ワッカ来訪) & 2.2 & 1.1 & 3.4 & 9.6 & 7.1 & **** \\
\hline 知床連山への登山(ワッカ来訪) & 6.3 & 3.5 & 11.4 & 13.1 & 8.9 & $* * *$ \\
\hline 羅臼湖へのハイキング(ワッカ来訪) & 4.0 & 5.2 & 10.1 & 12.1 & 14.3 & $* * *$ \\
\hline バードウオッチング(ワッカ来訪) & 3.4 & 3.9 & 4.1 & 10.6 & 8.9 & **** \\
\hline
\end{tabular}

や山々の眺め”, “フレペの滝や遊歩道の散策”, “岩尾別・セセキ・ 熊の湯での入浴”“知床連山への登山”であった。

利用行動の選択率について, 多重比較検定の結果, 有意差が示 された内容を表一13 に示した。“知床五湖の遊歩道の散策”, “知 床横断道路沿線と峠からの眺め”, “野生動物の写真撮影・観察” は 2004 年〜2005 年を境に, 減少傾向にあり, “エコッアーに参 加”といった，より深く自然に接する利用行動が増加傾向を示し た。また, “カムイワッカの入浴”は 2004 年に突出して多く, い わゆる駆け込み型の利用も散見された。

多重比較検定の結果を整理した（表一12）。

表ー11 調査地別にみた、利用行動の調査年による差異(多重比較検定)

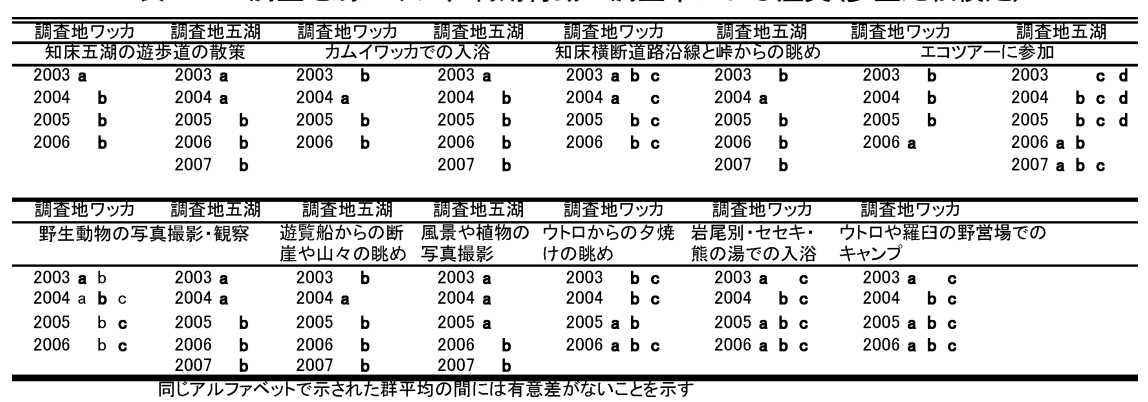

表ー12 カムイワッカ来訪別にみた、利用行動の調査年による差異(多重比較検定)

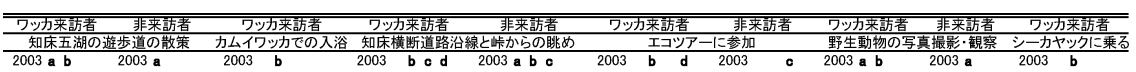

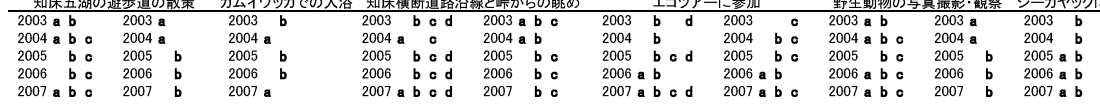

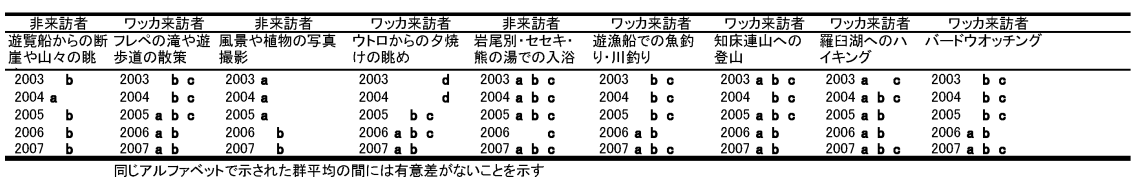

有意差を示した対象を示すと，知床五湖の 遊歩道の散策について, ワッカ来訪者では 2003 年, 2004 年と 2007 年, 2005 年 20 06 年に, 非来訪者では 2003 年 2004 年, 2005 年〜2007 年に区分された。カムイワッ カでの入浴について, ワッカ来訪者では 2004 年と 2007 年, それ以外に区分された。 知床横断道路沿線と峠からの眺めについて, ワッカ来訪者では 2004 年, 2007 年とそれ 以外に, 非来訪者では, 2003 年, 2004 年, 2005 年〜2007 年に区分された。エコッアー に参加について, ワッカ来訪者では各年に, 非来訪者では, 2003 年, 2004 年〜2005 年, 2006 年, 2007 年に区分された。野生動物 の写真撮影・観察について, ワッカ来訪者 では 2003 年, 2005 年, それ以外に, 非来 訪者では, 2003 年〜2004 年, 2005 年〜20 07 年に区分された。シーカヤックに乗る について， ワッカ来訪者では 2003 年〜20 04 年, 2005 年〜2007 年に区分された。遊 
覧船からの断崖や山々の眺めについて, 非来訪者では, 2004 年 とそれ以外に区分された。フレペの滝や遊歩道の散策について, ワッカ来訪者では 2003 年 2004 年, 2005 年, 2006 年〜2007 年 に区分された。風景や植物の写真撮影について, 非来訪者では 2003 年 2005 年, 2006 年 2007 年に区分された。ウトロからの 夕焼けの眺めについて，ワッカ来訪者では 2003 年〜2004 年, 2005 年, 2006 年, 2007 年に区分された。岩尾別・セセキ・熊の 湯での入浴について, 非来訪者では, 2006 年とそれ以外に区分 された。遊漁船での魚釣り・川釣りについて, ワッカ来訪者では, 2003 年 2005 年, 2006 年, 2007 年に区分された。知床連山への 登山について, ワッカ来訪者では, 2004 年, 2003 年と 2005 年, 2006 年〜2007 年に区分された。羅臼湖へのハイキングについて, ワッカ来訪者では， 2003 年， 2004 年と 2007 年， 2005 年 2006 年に区分された。バードウオッチングについて, ワッカ来訪者で は 2003 年〜2005 年, 2006 年, 2007 年に区分された。

利用行動の選択率について, 多重比較検定の結果, 有意差が示 された内容を表 -14 に示した。知床五湖の遊歩道の散策”, “知 床横断道路沿線 と峠からの眺め”, “野生動物の写真撮影・観察” は 2004 年〜2005 年を境に, 減少傾向にあり, “エコッアーに参 加”“シーカヤックに乗る”, “バードウオッチング”といった， より深く自然に接する利用行動が増加傾向を示した。また, “力 ムイワッカの入浴”は 2004 年に突出して多く, いわゆる駆け込 み型の利用も散見された。

\section{4. 考察}

利用者数について, カムイワッカで 2004 年と 2005 年の利用者 数が他の年度と比べて 20 40\%近く増加し, 知床五湖で 2005 年 と 2006 年は $20 \%$ 近く増加するなど，世界自然遺産登録前後で, 知床国立公園の利用において量的変化が起きていた。その前後に あたる 1999 年から 2007 年に郵送法による調査を実施しており, 回収率が, 調查地ワッカで 2003 年以降, 調査地五湖で 2004 年以 降, それ以前に比へ，変化したことは, 母集団である利用者に, 何らかの変化が起きたことを示唆する現象であると推測された。

2 ヶ所の調査地でのサンプリング対象の個人属性のうち, 年齢 については，2005 年以降，明らかな差がみられ，20 代以下や 30 代の割合が減少した。2005 年以降に起きたサンプリング対象の 変化は, 利用を取り巻く環境変化をきっかけに, 利用者全体に対 する, 若い世代の方々の割合が減少していることを示唆しており, 母集団である利用者の質的特性が変化していると解釈される。

また，車両規制に関する最初の情報源について経年的（2001 年〜2007 年）変化を調査地毎にみると，共通して，テレビにつ いては世界遺産登録年前後に増加し, 関係雑誌については 2003 年以降増加するなどマスコミへの掲載頻度の上昇による影響があっ たとみられる。また, 2003 年以降インターネットの増加は, 社 会的普及の影響もあるとみられる。一方，現地での規制看板は， その前後を境に以降減少しており, マスコミやインターネットな ご他の媒体での普及が進んだ結果と解釈される。カムイワッカ来 訪の有無で利用者を区分し比較した場合でも，同様の結果となっ たことから，情報源のように社会的変化の影響を受ける恐れのあ る項目を調查する際は, 調查年だけでなく, 前後数年の変化をと らえて解釈する必要性があると考えられる。

「車両規制期間の長さ」について, 規制期間の変更（1999 年 は 16 日間，2000 2004 年は 23 日間，2005 年以降は 70 日間）に 対応して, 2004 年と 2005 年との間に有意差が確認された。「規 制期間と来訪時期の選択」について，“現地に来るまで規制を知 らなかったので考慮できなかった”割合は実行動に影響を受ける 対象 (調査地ワッカ) では遺産登録前年の 2004 年と 2005 年, 直 接影響を受けにくい対象（調査地五湖）では 2005 年と, 他の年
の間に有意差が認められた。利用規制から直接影響を受ける利用 者とそれ以外の利用者では, 来訪時期の選択の変化に時間的なず れがあることを示している。

「車両規制への評価」について，2005 年以降，車両規制期間 が大幅に伸び一般車両の立ち入りが禁止され，規制が厳しくなっ たにも関わらず，調査地ワッカにおいて「必要であり，理解する」 の割合が 2005 年以降，支持する割合が増加した。この結果は, 母集団において，2005 年以降の車両規制の強化にも関わらず, 車両規制に肯定的な利用者が増加したことを示している。

利用行動について, “知床五湖の遊歩道の散策”, “知床横断道 路沿線と峠からの眺め”，“野生動物の写真撮影・観察”は 2004 年〜2005 年を境に, 減少傾向にあり, “エコッアーに参加”や “シーカヤックに乗る”，“羅臼湖へのハイキング”といった，よ り深く自然に接する利用行動が増加傾向を示した。また，“力ム イワッカの入浴” は 2004 年に突出して多く，いわゆる駆け込み 型の利用も散見されるなど，利用行動が利用環境への変化に対応 すると同時に，多様化しつつあることが読み取れる。したがって， 利用を取り巻く環境が変化する状況下では, 複数年にわたる継続 調査を行い，その趨勢や傾向をとらえた上で，単年度毎の調査結 果の解釈をする必要があるといえる。

知床での調查では複数個所で長期間，同じ設問を同じ方法で繰 り返したことで，多くの項目で調査年による有意差が確認された。 このことは，これまでの単年度および 1 箇所の調査から得た結果 について, 結果の数值の安定性や再現性に疑問があることを示し ている。利用の量的側面については, 継続的調查がすすめられて きたが，利用の質的側面ともいえる利用者意識から捉えられる変 化についても，継続的モニタリングを行う必要があるといえよう。 また，大雪山国立公園高原地区での調査結果から，年齢や，集団 人数, 住所の違いによって, アンケート回答への忌避の程度差が あること確認されおり ${ }^{11)}$ ，サンプリング手法自体についても論議 する必要があると考えられる。

謝辞：調査に際しご協力ならびにご理解を頂いた環境省釧路自然 保護事務所，地元関係機関，利用者に謝意を表する。

\section{補注および引用文献}

1) Watson, A. E., D. N. Cole, D. L. Turner and P. S. Reynolds (2000): Wilderness recreation use estimation A handbook of methods and systems : General Technical Report RMRS-GTR-56, USDA Forest Service, Rocky Mountain Research Station, Fort Collins, Colorado, US., 198pp.

2 ）山本泰裕・伊藤弘・小野良平・下村彰男（2006）：GPS を用いた新宿 御苑における利用者の行動バターンに関する研究：ランドスケープ研 究 69(5), 601-604

3 ）青木陽二編（2000）: 自然風景地の利用調查法 : 国立環境研究所報告 第 155 号, $120 \mathrm{pp}$

4 ）小林昭裕（2007）：自然公園における利用動態を把握するための調查 手法を改善する上での課題：環境情報科学論文集 $21,171-176$

5 ）国立公園協会（1978）：国立公園利用動態等調查報告書：国立公園協 会, 東京, $424 \mathrm{pp}$

6 ）小林昭裕（1999）：登山にみられる目的地や来訪時期の選択に関する 研究：ランドスケープ研究 62(5)，709-714

7 ) Manning, R.E. (1999): Studies of outdoor recreation (second edition): Oregon State University Press, Corvallis, 374pp

8 ）小林昭裕（2008）：知床国立公園の適正利用を図る上で各々の場の望 ましい空間特性に対する利用者の評価：ランドスケープ研究 71 (5), 645-650

9 ）知床国立公園の利用者数は，環境省釧路自然環境事務所の資料に基づ <。

10）林知己夫（1984）：現代人の統計 2 社会調查の基本：朝倉書店, 26-59

11）小林昭裕（2003）：山麓周遊路での利用動態にかかわる要因と利用動 態の調查手法について－紅葉時期の大雪山国立公園高原地区の沼巡り を事例としてー：環境情報科学論文集 $17,173-178$ 